\title{
The James Owens Site (41TT769) in the Sulphur River Basin of Northeast Texas
}

Mark Walters

Heritage Research Center, Stephen F. Austin State University

Bryan Boyd

Bo Nelson

Heritage Research Center, Stephen F. Austin State University

LeeAnna Schniebs

Timothy K. Perttula

Heritage Research Center, Stephen F. Austin State University

Follow this and additional works at: https://scholarworks.sfasu.edu/ita

Part of the American Material Culture Commons, Archaeological Anthropology Commons, Environmental Studies Commons, Other American Studies Commons, Other Arts and Humanities Commons, Other History of Art, Architecture, and Archaeology Commons, and the United States History Commons

Tell us how this article helped you.

This Article is brought to you for free and open access by the Center for Regional Heritage Research at SFA ScholarWorks. It has been accepted for inclusion in Index of Texas Archaeology: Open Access Gray Literature from the Lone Star State by an authorized editor of SFA ScholarWorks. For more information, please contact cdsscholarworks@sfasu.edu. 


\section{The James Owens Site (41TT769) in the Sulphur River Basin of Northeast Texas Creative Commons License (c) $($ ) $(9)$}

This work is licensed under a Creative Commons Attribution-NonCommercial 4.0 International License 


\title{
The James Owens Site (41TT769) in the Sulphur River Basin of Northeast Texas
}

\author{
Mark Walters, Bryan Boyd, Bo Nelson, LeeAnna Schniebs, \\ and Timothy K. Perttula
}

\section{INTRODUCTION}

The James Owens site (41TT769) is an apparent Middle to Late Caddoan settlement that was investigated in June 2001 at the request of the landowner, Mr. James Owens of Irving, Texas. The landowner is planning on building a house here in the future, and during the course of clearing the land and constructing a gravel drive way to the future house site, he noted some archeological materials on the surface. Discussions between Mr. Owens, Bryan Boyd (Texas Archeological Steward Network), and Mark Parsons, regional archeologist for the Texas Historical Commission, led to the limited investigations reported on here. The work we conducted was designed to obtain information on the age and content of the James Owens site, and determine what further archeological steps might be necessary to preserve the site and the information it contains.

The James Owens site is situated on a small and heavily overgrown natural rise near the edge of an expanse of "moundy uplands" (Roberts 1990) in the Post Oak Savannah. Immediately to the south is a flat stream terrace and floodplain of White Oak Creek, a tributary of the Sulphur River, and the current channel of White Oak Creek lies about $4 \mathrm{~km}$ to the south of the site. At the time of the 2001 investigations, the rise had been partially cleared by the landowner, with a gravel road leading from a Farm-to-Market road to the site itself (Figure 1). Lithic and ceramic artifacts were visible on the surface in the clearing.

\section{EXCAVATIONS}

The June 2001 investigations consisted of 10 shovel tests and $31 \times 1 \mathrm{~m}$ units, all of which contained prehistoric archeological materials. At least two shovel tests (ST 1 and ST 10), but possibly three others (ST 4, 7, and 9), were located in a ca. 20-30 cm thick midden deposit (Fea. 1). The Woodtell-Raino complex sediments in the midden area consisted of a ca. $30 \mathrm{~cm}$ dark brown to very dark brown sandy loam overlying a dark yellowish-brown sandy loam that extended to ca. $50 \mathrm{~cm}$ bs (Figure 2). Outside the midden area, the A and E horizon sediments were lighter in color, and ranged in thickness from 40 to $80 \mathrm{~cm}$ in thickness; the deepest sediments were recorded in ST 2 on the north side of the natural rise. Feature 2, a small charcoal-stained pit (ca. $35 \mathrm{~cm}$ in diameter), was documented between $15-54 \mathrm{~cm}$ bs in Unit 3 .

\section{RADIOCARBON AND OCR DATING}

A sample of 53 charred hickory nutshells weighing $3.1 \mathrm{~g}$ were collected from the midden deposits in a small column in Unit 1 (10-30 cm bs) for radiocarbon dating by Beta Analytic, Inc. The conventional radiocarbon age of the nutshells is $740 \pm 70$ B.P. The calibrated intercept is A.D. 1280, and at two sigma, there is a $95 \%$ chance that the calibrated age of the nutshells in the midden falls between A.D. 1180-1390 (Stuiver et al. 1998; Talma and Vogel 1993). 
We also collected Oxidizable Carbon Ratio (OCR) samples (200 g of sediments) from a column in Unit 1 (see Figure 2). The samples were collected at 5 or $10 \mathrm{~cm}$ intervals (Table 1), and analyzed by Oxidizable Carbon Ratio, Inc. of Essex, Vermont.

The range of OCR dates in the midden deposits is A.D. 1241-1643 (see Table 1). The one pedogenic marker in the column — being marked by an increase in soil $\mathrm{pH}$, the frequency of coarse sediment particles,

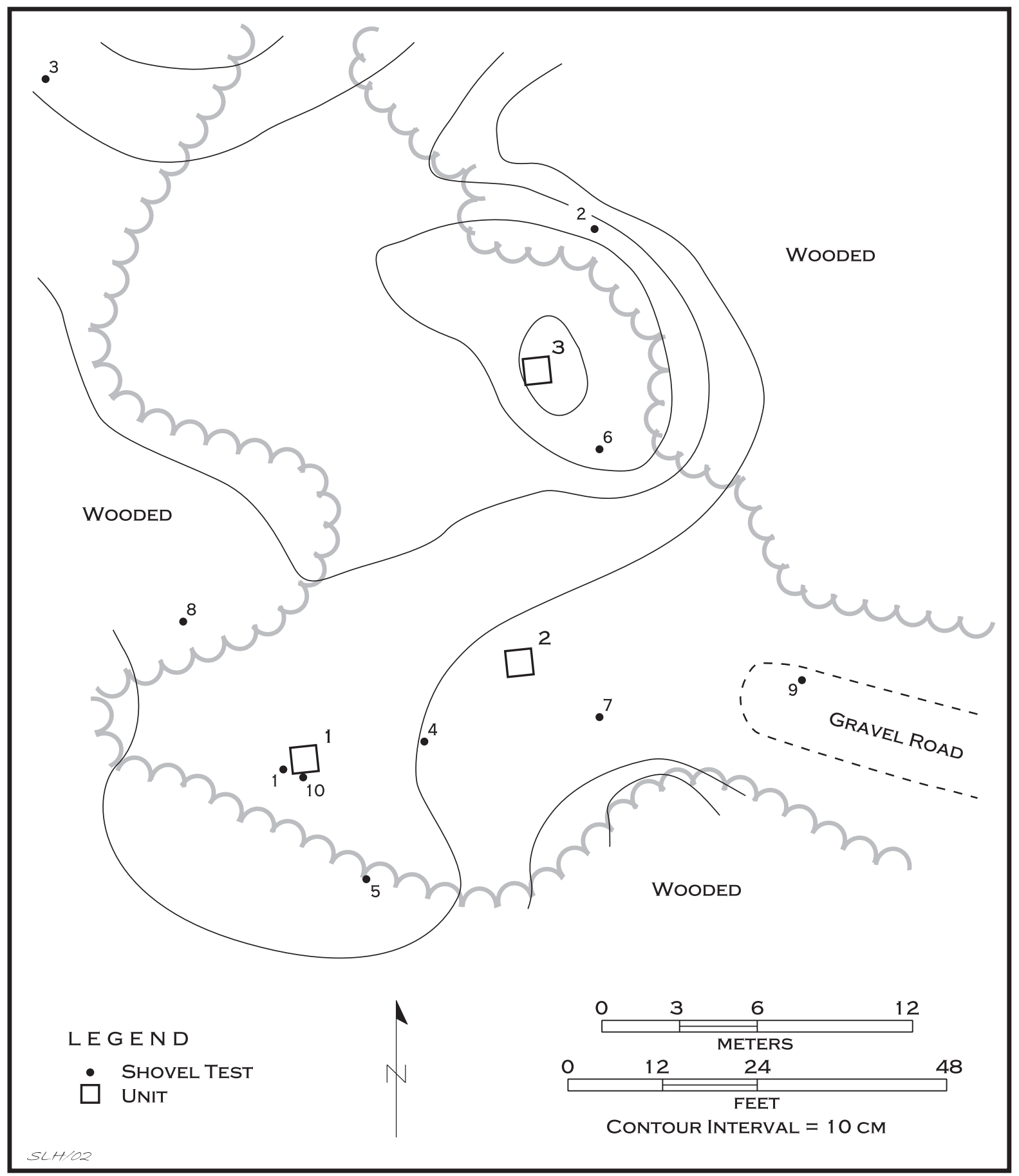

Figure 1. Map of the James Owens site (41TT769). 
and an increase in the OCR ratio (Douglas Frink, 2001 personal communication) - dates from A.D. 1391-1423. The age of this pedogenic marker suggests that the midden has been undergoing pedogenic development since about that time, and this strongly implies that the midden itself dates to this same time range.

Taken together, the one calibrated radiocarbon date and the OCR dates suggest that the James Owens site midden accumulated between ca. A.D. 1200 and the early 15 th century.

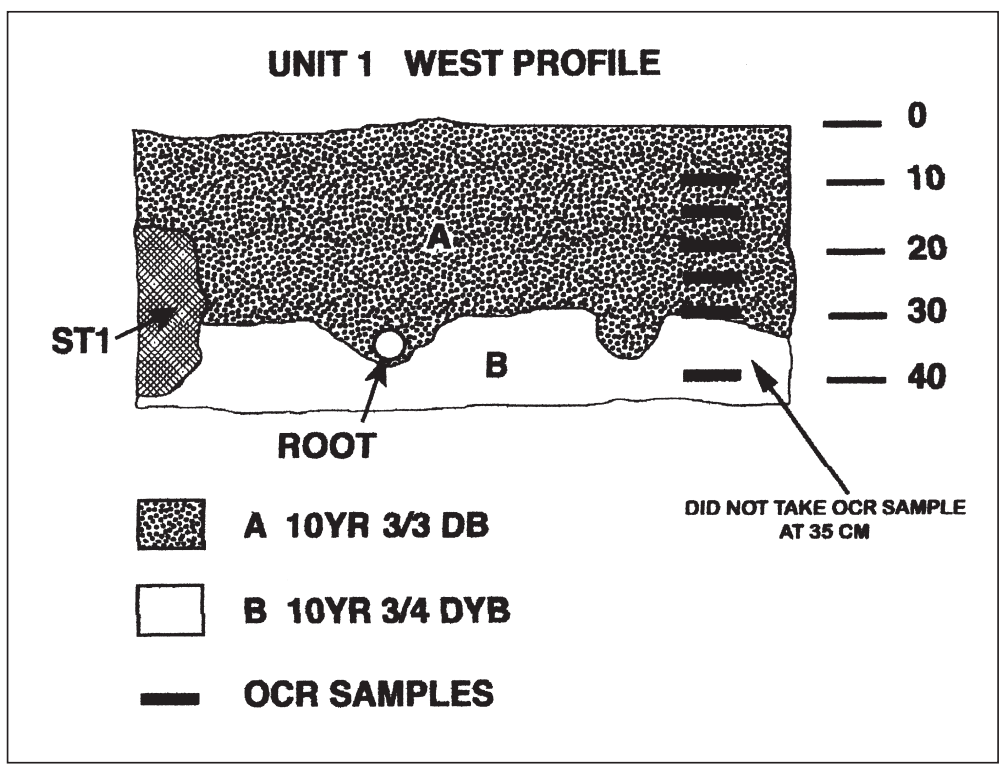

Figure 2. Unit 1 profile, west wall. Zone A is the midden deposit.

\section{ARTIFACT ANALYSES}

A wide variety of prehistoric artifacts were recovered in the investigations at the James Owens site, primarily lithic debris, daub, and plain and decorated ceramic sherds (Table 2). The highest densities of artifacts were in ST 1 and Unit 1, apparently in the best-preserved part of a Middle to Late Caddoan midden deposit. Artifact densities in ST 1 and Unit 1 were a very substantial 3150-3280 artifacts per square meter. In units 2 and 3, outside the midden, artifact densities ranged from 826.7875 per square meter.

Table 1. OCR Dates from the James Owens Site (41TT769).

\begin{tabular}{|c|c|c|c|c|}
\hline Sample Depth & Sample No. & $\begin{array}{c}\% \text { Organic } \\
\text { Carbon }\end{array}$ & $\begin{array}{c}\text { OCR Date } \\
\text { and sd (B.P.) }\end{array}$ & $\begin{array}{l}\text { Age Range } \\
\text { (A.D.) }\end{array}$ \\
\hline \multicolumn{5}{|c|}{ Midden Samples } \\
\hline $8-10 \mathrm{~cm}$ & ACT-5519 & 2.925 & $307-325$ & A.D. $1625-1643$ \\
\hline $13-15 \mathrm{~cm}$ & ACT-5520 & 2.068 & $378-400$ & A.D. $1550-1572$ \\
\hline $18-20 \mathrm{~cm}$ & ACT-5521 & 1.791 & $527-559$ & A.D. $1391-1423$ \\
\hline $23-25 \mathrm{~cm}$ & ACT-5522 & 1.458 & $647-685$ & A.D. $1265-1303$ \\
\hline $28-30 \mathrm{~cm}$ & ACT-5523 & 1.181 & $669-709$ & A.D. $1241-1281$ \\
\hline \multicolumn{5}{|c|}{ E-horizon Sample below the Midden } \\
\hline $38-40 \mathrm{~cm}$ & ACT-5524 & 0.889 & $786-834$ & A.D. $1116-1164$ \\
\hline
\end{tabular}


Table 2. Prehistoric Artifacts from the James Owens site.

\begin{tabular}{|c|c|c|c|c|c|c|c|c|c|c|}
\hline Provenience & DS* & PS & $\mathrm{DP}$ & AP & $\mathrm{T}$ & $\mathrm{LD}$ & $\mathrm{Da}$ & NS & $\mathrm{B} / \mathrm{Sh}$ & $\mathrm{Ch}$ \\
\hline Surface & 6 & 12 & - & - & - & 27 & - & - & - & - \\
\hline ST 1 & 7 & 12 & - & 1 & 1 & 53 & 76 & 11 & 21 & 8 \\
\hline ST 2 & 4 & 6 & 1 & - & - & 37 & 1 & - & 1 & - \\
\hline ST 3 & - & - & - & - & - & 2 & - & - & - & - \\
\hline ST 4 & - & 3 & - & - & - & 10 & 3 & 1 & - & - \\
\hline ST 5 & - & 1 & - & - & - & 12 & 17 & - & - & - \\
\hline ST 6 & - & 1 & - & - & - & 31 & - & 1 & - & - \\
\hline ST 7 & 2 & 3 & - & - & - & 10 & 1 & 11 & 1 & - \\
\hline ST 8 & - & 2 & - & - & - & 14 & 4 & - & - & - \\
\hline ST 9 & 1 & 1 & - & - & - & 9 & 1 & 1 & 1 & - \\
\hline ST 10 & 3 & 7 & - & - & 1 & 22 & 27 & 9 & 6 & 3 \\
\hline Unit 1 & 33 & 138 & - & 4 & - & 455 & 541 & 33 & 95 & 23 \\
\hline Unit 2 & 14 & 30 & - & - & - & 191 & - & 9 & - & 4 \\
\hline Unit 3 & 4 & 30 & 2 & 1 & 1 & 299 & 6 & 2 & - & 6 \\
\hline Totals & 74 & 246 & 3 & 6 & 3 & 1172 & 677 & 80 & $125 * *$ & 44 \\
\hline
\end{tabular}

*DS=decorated sherd; $\mathrm{PS}=$ plain sherd; $\mathrm{DP}=$ dart point; $\mathrm{AP}=$ arrow point; $\mathrm{T}=$ chipped stone tool; $\mathrm{LD}=$ lithic debris; $\mathrm{Da}=$ daub; $\mathrm{NS}=$ nutshell; $\mathrm{B} / \mathrm{Sh}=$ bone and mussel shell; $\mathrm{Ch}=$ charcoal.

**Does not include flotation samples.

\section{Ceramics}

The initial investigations at the James Owens site produced a total of 320 sherds, of which 74 are decorated (see Table 2). The plain/decorated sherd ratio is 3.32 . The 246 plain sherds include three bases (two flat and one rounded) and nine plain rims (five everted, with rounded and rolled-out lips, and four that are direct, with rounded lips). About $77 \%$ of the sherds are from units 1-3, another 18 are from the general surface, and 53 were found in ST 1-10.

Of the 320 sherds, $72.5 \%$ are tempered with bone and grog. Another $26.3 \%$ have only grog temper, and four sherds $(1.3 \%)$ are red-slipped sherds with shell tempering. There is considerable variation in the temper composition in different parts of the site. Temper of the sherds from Unit $2(n=44)$ are $59 \%$ bone and grog, and $40.9 \%$ grog, while in Unit 1 ( $n=171$ sherds), $73.7 \%$ have bone and grog temper, $24.6 \%$ are grog-tempered, and there are three shell-tempered sherds. Unit 1 was placed adjacent to ST 1 (which has the remaining red-slipped shell-tempered sherd) and ST 10, both in a midden deposit. ST 1 and ST 10 sherds also have a high proportion of bone temper compared to the sherds in Unit 2. There are also a considerable variation in the design elements on the sherds (see below).

Vessel forms represented in the sherds include small jars with everted rims $(n=12)$ or direct rims $(n=9)$, and they have rounded $(n=20)$ or flat $(n=1)$ lips. Eleven of the lips are also rolled-out or folded to the exterior, and one has been rolled-out and smoothed. A heavy sooty coating on the exterior of some of the sherds indicates the jars were used for cooking over an open fire. Overall, the average sherd thickness is $6.2 \mathrm{~mm}$, with the decorated sherds slightly thinner $(6.0 \mathrm{~mm})$. 


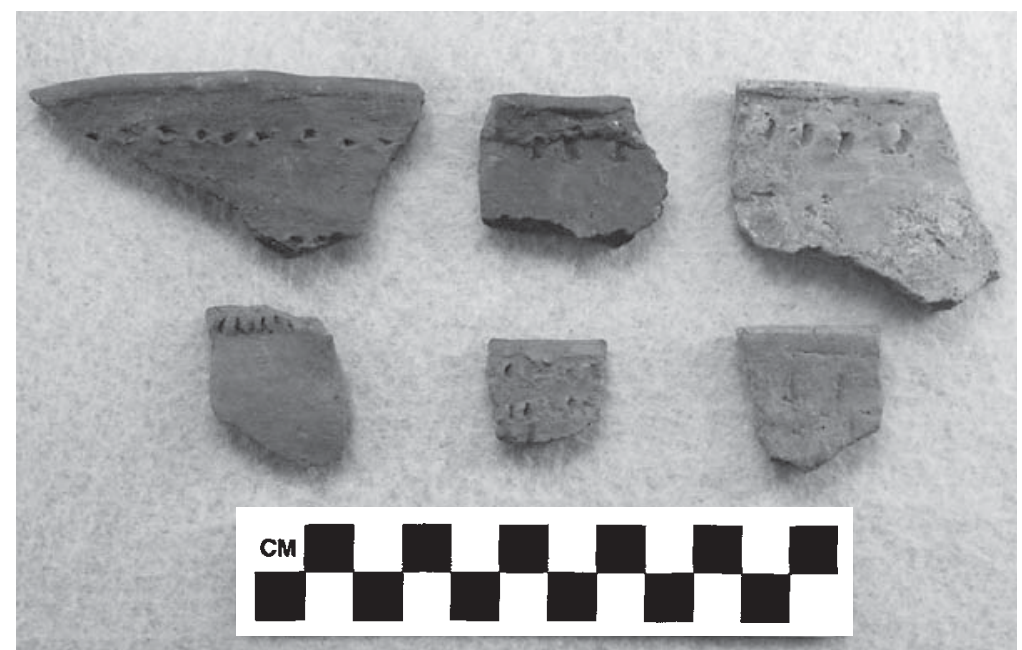

Figure 3. Punctated rim and brushed sherds from the James Owens site.

Firing conditions indicate that $63.8 \%$ of the sherds have been fired in a reducing or low oxygen environment (e.g., Teltser 1993); about $57 \%$ of these sherds were subsequently cooled in a high oxygen environment. The proportion of sherds that are from vessels fired in a high oxygen environment is $18.4 \%$, and $17.8 \%$ are from vessels that have been incompletely oxidized during firing.

The 74 decorated sherds include 12 rims. Horizontal rows of tool punctates (tear-drop to rectangular-shaped) are the most common ( $\mathrm{n}=16$, or $21.6 \%$ of the decorated sherds) form of decoration (Figure 3 ). Included in these sherds are eight punctated rims (representing $67 \%$ of the 12 decorated rims), one of which had a single row of tool punctates below the lip followed by horizontal brushing or rough incised lines. One punctated sherd from ST 2 has randomly placed half-moon shaped indentations. Absent in the assemblage are punctated sherds with large gouge marks or punch and drag forms.

Next in abundance are engraved sherds ( $\mathrm{n}=14,18.9 \%$ of the decorated sherds), followed by sherds with incised decorations $(n=9,12.2 \%$ ) (Figure 4). The engraved sherds primarily have single or parallel lines, either straight or curvilinear. One engraved sherd from Unit 1 has a horizontal line at the point of carination, with opposing lines forming panels (see Figure 4, top row, second from left), and another has a circular engraved element (see Figure 4, top row, upper left). The incised sherds include those with crosshatching on the rim as well as horizontal and diagonal lines (see Figure 4, top row, third and fifth from left).

There are also nine neckbanded sherds (12.2\%), including at least one rim (Figure 5), and another with an appliqued node below the lip (Figure 5, right). Several of the neck-banded sherds from more recent investigations are from shell-tempered Nash Neck Banded cooking jars. Another eight sherds $(10.8 \%$ of the decorated sherds) have appliqued elements. Some of the appliqued sherds, where sherd size was large enough to distinguish decorative motifs, formed chevrons, while others were single fillets, occasionally with punctations on the fillet (see

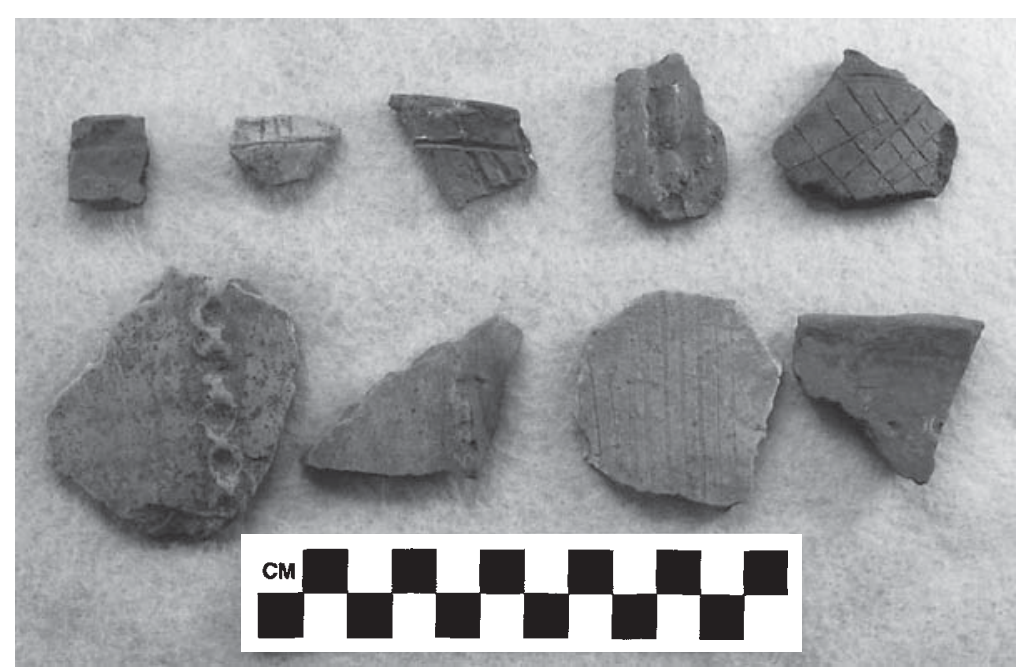

Figure 4. Engraved, incised, appliqued, and tool punctated sherds from the James Owens site. 


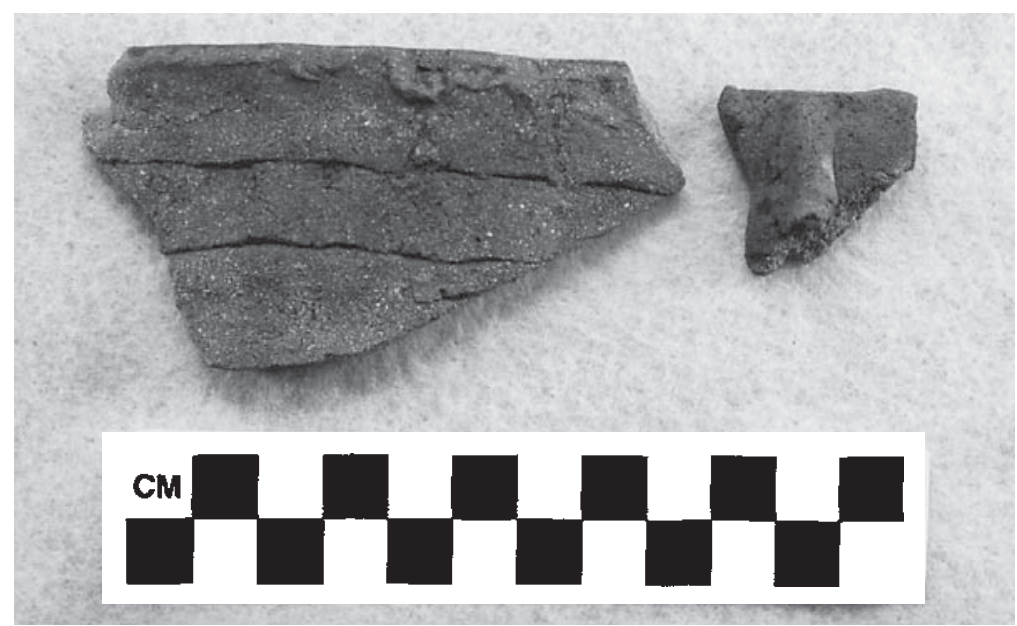

Figure 5. Nash Neck Banded rim sherds from the James Owens site.
Figure 4, top row, fourth from left, and bottom row, first and second from left).

Brushed sherds account for $14.9 \%$ of the decorated sherds, but their method of decoration, composition, and distributions vary across the James Owens site. Unit 1 had three brushed sherds, one similar to Pease Brushed-Incised with faint vertical brushing marks separated by a vertical appliqued ridge. The other two brushed sherds have thin parallel brushed lines, and one is a rim with a single

line of punctates above horizontal brushed/incised lines (see Figure 3, top row, first from left). All three sherds had bone and grog temper. About $73 \%$ of the brushed sherds are from Unit 2, and seven of the eight sherds were grog-tempered and were brown or light brown in color. Brush marks were light on some, and overlapped, while others had wider and more evenly spaced brushing marks (see Figure 3, bottom row, third from left). The brushed sherd from Unit 3 is probably also from a Pease Brushed-Incised vessel as it has parallel brushing marks that end at an eroded but raised area that is probably an appliqued fillet.

There are 17 red-slipped body sherds in the sherd assemblage; they are red-slipped on both exterior and interior sherd surfaces. Thirteen are from Unit $1(0-40 \mathrm{~cm} \mathrm{bs})$, three are from Unit $3(0-10 \mathrm{~cm} \mathrm{bs})$, and one red-slipped sherd was found in Unit 2 (10-20 cm bs). Four of the red-slipped sherds are shelltempered, and the remainder were tempered with grog and bone. Most (82\%) are from vessels fired in a reducing environment and cooled in a high oxygen environment, and the remainder were incompletely oxidized during firing.

There were six sherds with punctated-incised decorations. These have straight horizontal lines separating rows of tool punctations. One Unit 1 sherd has a row of tool punctates in a wide area between three parallel and straight lines.

\section{Daub}

There are 677 pieces of daub collected from the excavations. The majority $(\mathrm{n}=541)$ are from Unit $1, \mathrm{ST}$ 1, and ST 10, all in the midden. The distribution of daub in the midden suggests that the midden marks the approximate location of a burned Middle to Late Caddoan house structure (This was confirmed in later April 2002 excavations, when a clay-lined hearth was documented in another 1 x $1 \mathrm{~m}$ unit about $2 \mathrm{~m}$ northnorthwest of Unit 1; the analysis of these excavations is still in progress by the authors), or that after the structure burned, the house debris was cleaned-up and dumped in the midden. The remainder of the daub from the other proveniences consists of small and eroded fragments.

The daub from the midden ranged from ca. $3 \mathrm{~cm}$ diameter pieces to small, rounded, orange-colored fragments, several of both kinds with grass impressions. There appears to be more sand in the daub material than in the clay used to make the ceramic vessels, and the daub matrix also contains small sandstone 
fragments which were absent in the ceramic sherds. Most of the recognizable pieces of daub have one smoothed surface that was either tan or gray in color. The other surface is mostly blackened and has grass/ cane impressions, with the grass and cane oriented perpendicular to each other. A few pieces of daub had charred material or impressions sandwiched between two layers of clay, indicating that several layers were applied at once or that there were multiple refurbishing episodes.

The charred materials and the blackened daub imply that a prehistoric Caddo house burned and was either covered, creating a reducing atmosphere, or that the daub itself smothered the fire. A few of the smoothed surfaces are convex, suggesting that the smoothed surface was located on the exterior of the dwelling.

There has been considerable speculation about the use of daub in Caddo house construction: was the daub added as protection against the elements, as protection against fire, or perhaps did the clay daub surface serve a decorative function? In Northeast Texas Caddo sites, the use of daub appears to be more common north of the Sabine River. However, since daub is the result of thermal alteration, the location and preservation of daub around a structure must be studied in light of the processes that occur when a structure actually burns (Bankoff and Winter 1979).

\section{Lithic Tools}

The 12 chipped lithic tools include six arrow points or arrow point fragments, three Gary dart points, and three expedient flake tools (see Table 2); later work at the James Owens site also recovered a Yarbrough and several other small arrow points. The two identifiable arrow points are triangular Maud forms from ST 1 and Unit 1 (10-20 cm bs), both are made from quartzite (Figure 6, top row). Such arrow points were commonly made and used after ca. A.D. 1300/1400 in this part of the Sulphur River basin (see Fields et al. 1997; Sherman et al. 2002), and they may have continued in use until the $17^{\text {th }}$ century. They range from 14.1-18.8 $\mathrm{mm}$ in length, $9.4-10.0 \mathrm{~mm}$ in width, and $2.6-2.8 \mathrm{~mm}$ in thickness. Their basal concavities are 1.7-2.6 $\mathrm{mm}$ in height.

A parallel to slightly expanding stemmed and unifacially worked arrow point made of a local tan chert was found in Unit 1 $(10-20 \mathrm{~cm}$ bs), and a squarestemmed arrow point with prominent barbs was recovered in Unit 1 between $20-30 \mathrm{~cm}$ bs. This point was made from a heat-treated quartzite. The blades of two other arrow points-both also made from heat-treated quartzite-were found in Unit $1(20-30 \mathrm{~cm})$ and Unit 3 (20-30 cm bs).

The contracting stem dart points include a Gary, var. Camden specimen from Unit 3 (20-30 cm bs), and two Gary, var.

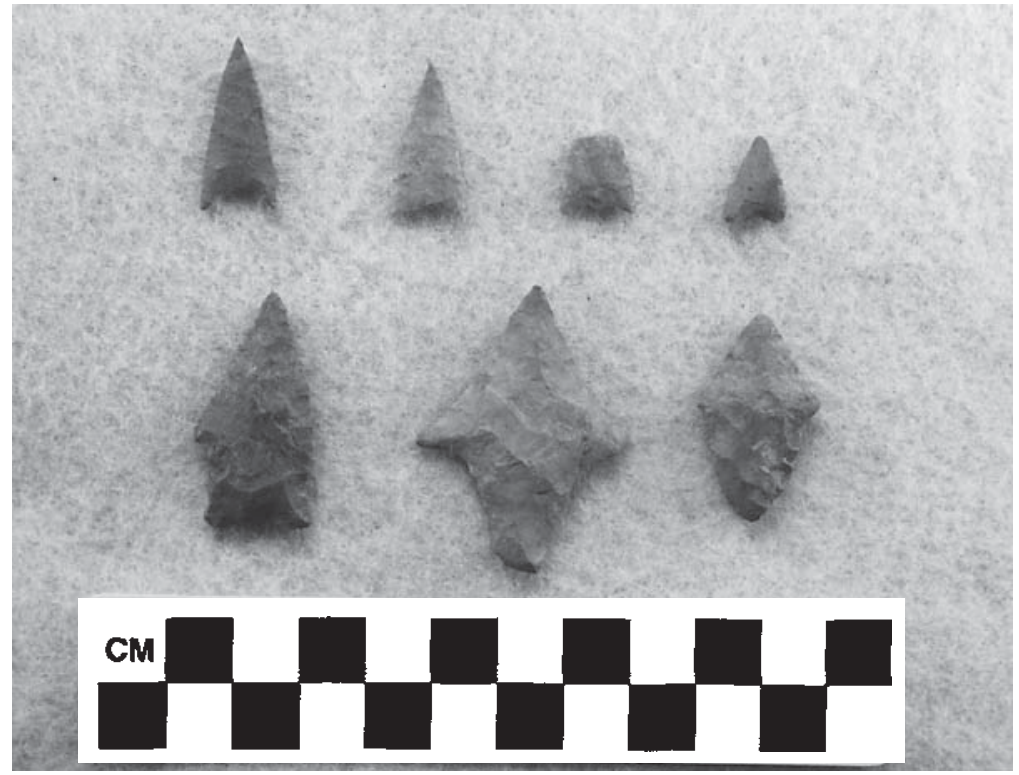

Figure 6. Maud arrow points and Yarbrough and Gary dart points from the James Owens site. 
Gary points from ST 2 and Unit 3 (20-30 cm bs) (see Figure 6, bottom row, second and third from left). All three Gary points were made from local quartzite. According to Schambach (1998), these contracting stem dart points were made and used during the Woodland period, perhaps between ca. 2800-1250 years ago, and their recovery at the James Owens site suggests it was periodically utilized by Woodland period peoples prior to the more intensive Middle to Late Caddoan settlement.

The expedient flake tools in ST 1, ST 10, and Unit 3 are on quartzite flakes. These tools have retouched and use-worn areas along the flake edge, and they were probably used for the cutting and scraping of moderately durable materials, including wood, leather, and green bone.

\section{Lithic Debris}

The prehistoric occupants of the James Owens site depended heavily on the procurement and use of locally available stone for the manufacture of chipped stone tools. More than $96 \%$ of the 1172 pieces of lithic debris are on the local quartzite $(n=1135)$ that could be procured from stream gravels along White Oak Creek and in upland lag gravels. Other locally available raw materials present in the lithic debris are petrified wood $(n=17)$, red chert $(n=1)$, brown chert $(n=1)$, and tan chert $(n=3)$. The few pieces of non-local lithic raw materials include gray chert $(n=8)$, a chalcedony $(n=1)$, white novaculite $(n=4)$, and gray novaculite $(n=2)$. These materials were probably obtained from Red River gravel sources below the mouth of the Kiamichi River, in Red River County, Texas, about $60 \mathrm{~km}$ to the north of the James Owens site.

About $37 \%$ of the local quartzite lithic debris has cortical remnants, and $29 \%$ of the petrified wood pieces are cortical. The amount of cortical flakes in the lithic debris assemblage, along with the many noncortical flakes that range from $0.64-2.54 \mathrm{~cm}$ in size, relate to the prehistoric inhabitants bringing the raw materials back to the site as nodules and cores for further reduction, rather than as flakes previously detached from cobble or pebble masses.

\section{Paleobotanical Remains}

Paleobotanical remains found at the James Owens site includes charred thick-shelled hickory (Carya sp.) nutshells $(n=80)$ and wood charcoal $(n=44)$. Most of the remains were found in the midden deposits (ST 1, ST 10, and Unit 1), and in ST 7, near the midden (see Figure 1 and Table 2). The nutshells are probably the product of being boiled in ceramic jars to obtain the oil (Gardner 1997:174), and the wood charcoal are charred and discarded pieces from the use of gathered wood in hearths and cooking pits.

\section{Mussel Shell}

The preservation of mussel shell in Northeast Texas prehistoric archeological sites is always a good indication that a site has a well-preserved midden deposit. Some 22 pieces of freshwater mussel shell were found only in ST 1 (0-50 cm bs) and Unit $1(10-30 \mathrm{~cm} \mathrm{bs})$.

\section{JAMES OWENS SITE (41TT769) FAUNAL ANALYSIS}

The investigation of the James Owens site (41TT769) yielded 175 faunal specimens. Total weight of the assemblage is 43.13 grams. Faunal material was recovered from five shovel test pits and one excavation unit. Depths range from 0-50 centimeters below surface $(\mathrm{cm} \mathrm{bs})$. The following sections discuss 
the methods employed in the faunal analysis, results of taxonomic identification and quantification, and distribution of these remains.

\section{Methodology}

All prehistoric vertebrate remains were inventoried and weighed. Excel 5.0 for Windows was used to manipulate the generated data. An Ohaus digital scale, Model CT600-S, was used to record bone weight. All fragments recovered were analyzed by the author, using comparative collections on loan from or housed at the Institute of Applied Sciences, Zooarchaeology Laboratory, University of North Texas, Denton, Texas. Occasional supplements were required, using conventional osteological keys such as Olsen (1964), Gilbert (1980), and Schmid (1972). Identifications were made to the most specific category possible depending on condition of the bone and available comparative material. Only positive identifications resulted in the assignment of elements to genus or species.

Standard zooarcheological methods have been used. The animal bones were inventoried and bagged by the excavators, then submitted for identification and quantification. Both unidentifiable and identifiable pieces were analyzed in similar fashion. That is, the same attributes were recorded: taxon, element and portion of that element, anatomical location of the element, condition of the bone and any notes on age, taphonomy, burning or breakage patterns, and presence of modification if applicable. Provenience information was also recorded.

Quantification of the assemblage is summarized as number of identified specimens per taxon (NISP) and as minimum number of individuals (MNI) for identified elements. MNI estimates were calculated according to the most frequently occurring element, based on symmetry and element portion (Munzel 1986). In some cases, complete long bones and proximal or distal ends were considered. In other cases, the presence of a single element constituted an MNI of one.

The faunal data tables included here are standard species lists with the number of occurrences for each animal. Those specimens regarded as unidentifiable (those coded to only class or order) have been consolidated into a few general categories. Elements of non-diagnostic skeletal value (ribs, vertebrae, and long bone shafts; Olsen 1964), are coded in an indeterminate category by class and/or size range. Specifically, specimens counted as "unidentifiable mammal" are of indeterminate size, and "large mammal" refers to a deer-size mammal. "Indeterminate vertebrate" includes the bones uncertain of class. Recording these specimens in a size category enables the most precise level of observation as the specimen allows. In small samples, taking note of weight and the size categories of nondiagnostic elements broadens the function of the bone assemblage. However, percentages referred to in this report are calculated by number of bones (NISP) rather than weight. Weights of specimens by unit number can be found in Table 3.

\section{Results}

The following section describes the vertebrate taxa recovered from the James Owens site. Taxonomic classes identified include fish, reptile, and mammal (artiodactyla only). The faunal assemblage is dominated by unidentifiable large mammal remains. None of the faunal specimens are modified. Number of identified specimens (NISP) and minimum number of individuals (MNI) for each taxon are summarized in Table 4, as are weights for each taxon and percentages of site assemblage. Composition of anatomical elements can be found in Table 5 . 
Table 3. Inventory of 41TT769 Faunal Assemblage.

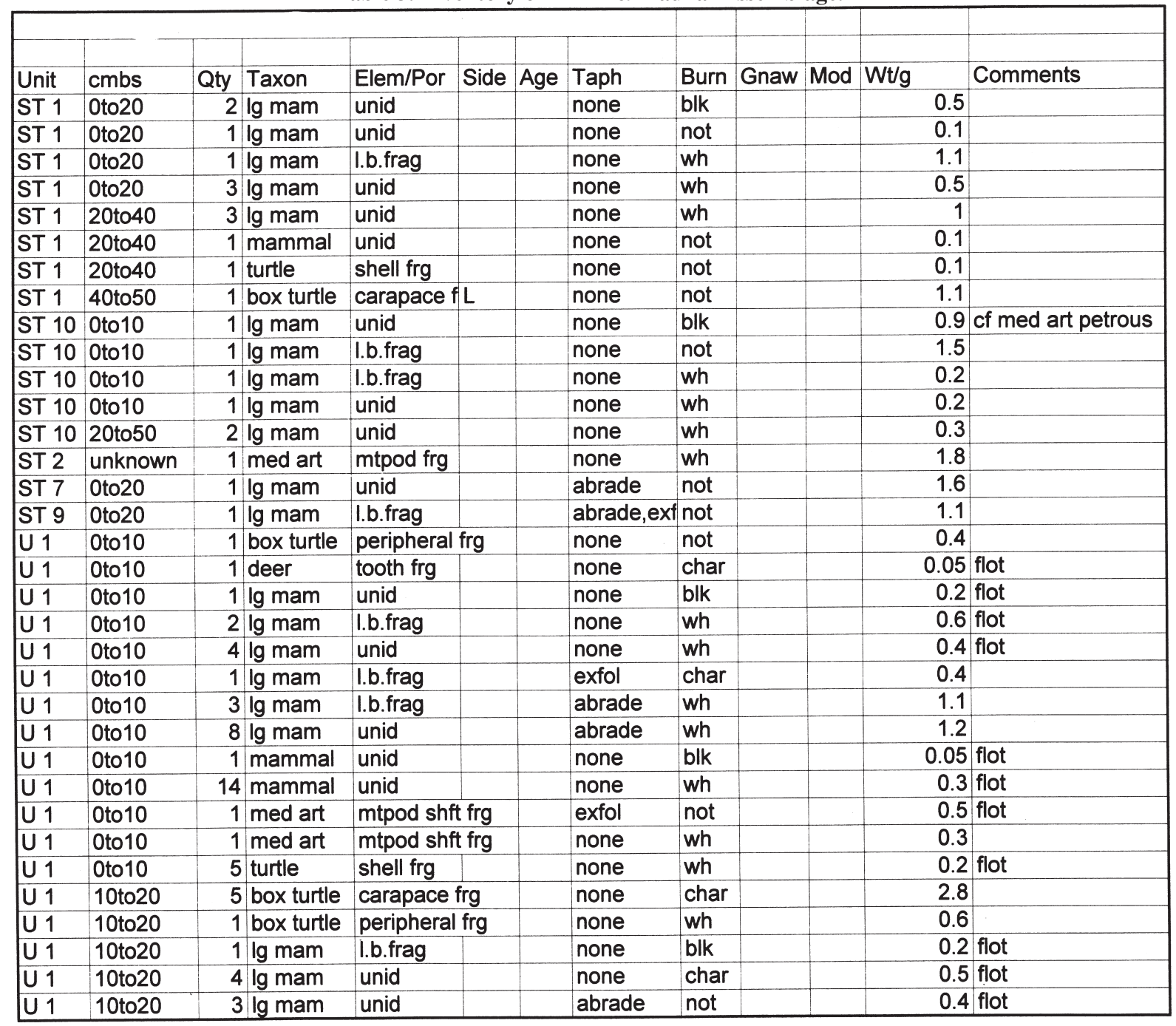

\section{Assemblage Composition}

\section{Class Osteichthyes}

Order indeterminate: Two very small cranial fragments from unidentifiable small-sized bony fish are present in the James Owens site faunal collection. Fragmentation prevented specific identification. The specimens were recovered from a flotation sample taken in Level $2(10-20 \mathrm{~cm}$ bs) of Unit 1 . The pieces are burned. The presence of fish remains in the collection is not unusual. Fish were used extensively by the Caddo Indians, with no known limitations on variety or size (Newcomb 1993). They were caught in several ways, employing trotlines: short lines were hung about a foot apart from a long line with hooks on each end baited with "dough bait" or meat. The line can be checked several times a day, yielding good-sized fish. The method is almost identical to the one used today.

Order Testudinata, Family Emydidae: Box turtle (Terrapene sp.) is represented by eight shell fragments from two units. Two levels in Unit 1 yielded seven fragments, and one fragment was recovered from Shovel Test 1 at 40-50 cm bs. The six pieces from Level $2(10-20 \mathrm{~cm} \mathrm{bs})$ in Unit 1 are burned. Box turtles, 
Table 3. (Continued)

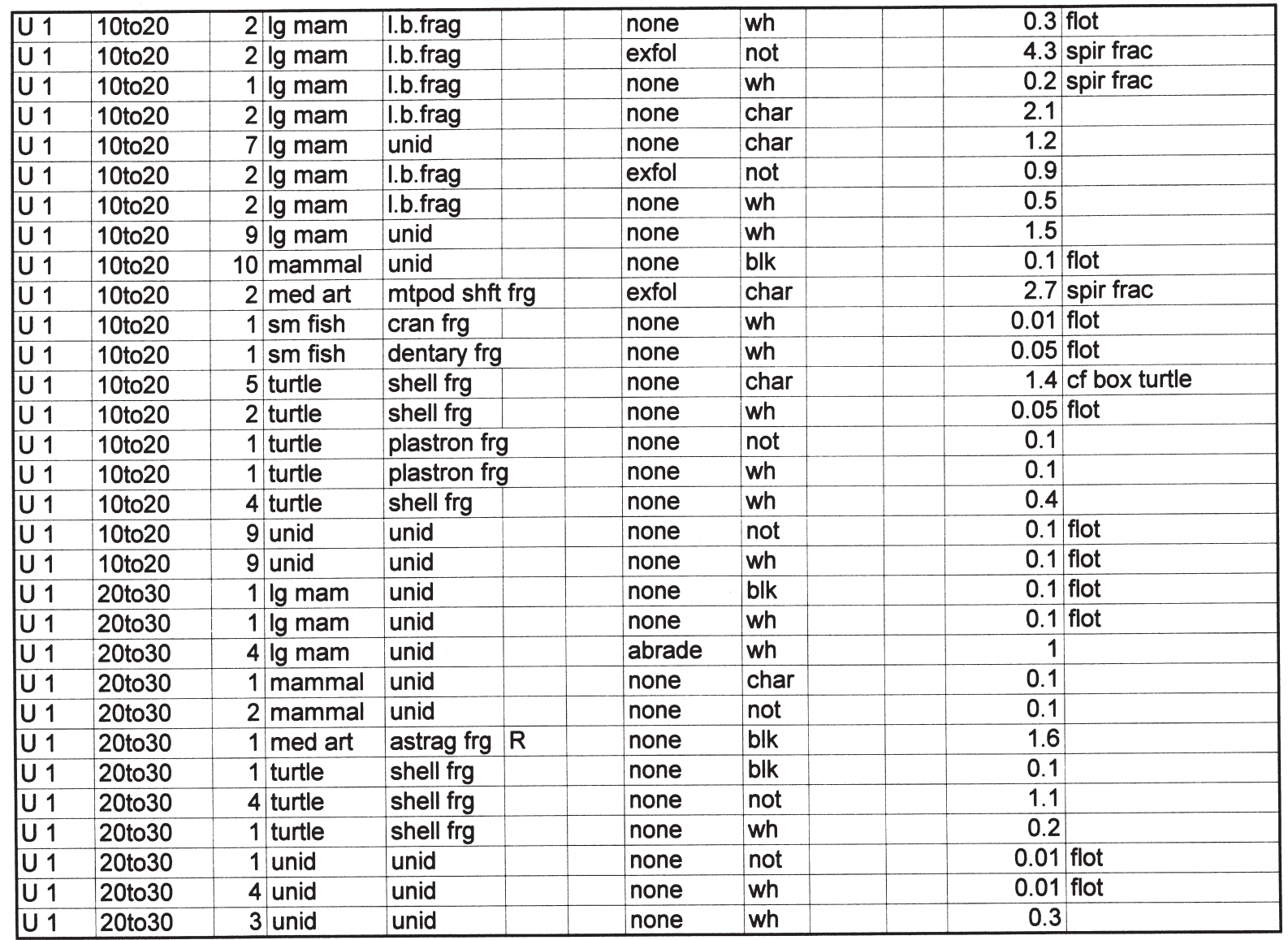

Table 4. Taxonomic Composition of 41TT769 Faunal Assemblage.

\begin{tabular}{|l|l|r|r|r|r|}
\hline & & & & \\
\hline Scientific Name & Common Name & NISP & MNI & \% of Site & Wt./g \\
\hline Vertebrata (indeterminate) & unidentifiable & 26 & & 15 & 0.52 \\
\hline Osteichthyes (small) & sm. bony fish & 2 & 1 & 1 & 0.06 \\
\hline Testudinata & turtle & 25 & & 14 & 3.75 \\
\hline Terrapene sp. & box turtle & 8 & 1 & 5 & 4.9 \\
\hline Mammalia (indeterminate) & unid. mammal & 29 & & 17 & 0.75 \\
\hline Mammalia (large) & lg. mammal & 78 & & 44 & 26.2 \\
\hline Artiodactyla (medium) & deer-size artiodactyl & 6 & & 3 & 6.9 \\
\hline Odocoileus sp. & deer & 1 & 1 & 1 & 0.05 \\
\hline & TOTAL & 175 & & 100 & 43.13 \\
\hline
\end{tabular}

which are strictly North American, range widely over the eastern and central United States and into the Southwest, and they also occur in many parts of Mexico. These are dry-land turtles that close their shells tightly when danger threatens (Conant 1975).

Order Testudinata (family indeterminate): A total of 25 shell fragments from unidentifiable turtle are included in the James Owens faunal collection. Turtle remains were recovered from the three levels in Unit 
Table 5. Composition of Faunal Elements from 41 TT769.

\begin{tabular}{|c|c|c|c|c|c|c|c|}
\hline \multirow{2}{*}{ Scientific Name } & \multirow[t]{2}{*}{ Common Name } & \multicolumn{2}{|c|}{ Element } & \multirow[b]{2}{*}{ cranial frag } & \multirow[b]{2}{*}{ long bone frag } & \multirow[b]{2}{*}{ podial frag } & \multirow[b]{2}{*}{ shell frag } \\
\hline & & unid & tooth frg & & & & \\
\hline Vertebrata (indeterminate) & unidentifiable & 26 & & & & & \\
\hline Osteichthyes (small) & sm. bony fish & & & 2 & & & \\
\hline Testudinata & turtle & & & & & & 25 \\
\hline Terrapene sp. & box turtle & & & & & & 8 \\
\hline Mammalia (indeterminate) & unid. mammal & 29 & & & & & \\
\hline Mammalia (large) & Ig. mammal & 56 & & & 22 & & \\
\hline Artiodactyla (medium) & deer-size artiodactyl & & & & 5 & 1 & \\
\hline \multirow[t]{2}{*}{ Odocoileus sp. } & deer & & 1 & & & & \\
\hline & TOTAL & 111 & 1 & 2 & 27 & 1 & 33 \\
\hline
\end{tabular}

1 , and the majority came from the second level $(10-20 \mathrm{~cm} \mathrm{bs}, \mathrm{n}=13)$. One specimen was found in Shovel Test 1 at $20-40 \mathrm{~cm}$ bs. Nineteen fragments from Unit 1 are burned.

\section{Class Mammalia}

Order Artiodactyl, Family Cervidae: Deer (Odocoileus sp.) is represented by one specimen recovered from a flotation sample taken in the first level $(0-10 \mathrm{~cm} \mathrm{bs})$ of Unit 1 . This tooth fragment is charred. Whitetail deer (Odocoileus virginianus) is the only species in Family Cervidae that currently occupies the project area, found in forests, swamps, and open brushy areas nearby (Burt and Grossenheider 1980). In Texas, whitetail deer prefer suitable brushy or wooded country throughout the state (Davis 1978). Whitetail deer are smaller in size, as compared to the larger mule deer of the western United States.

Medium artiodactyl is represented by six specimens. Three levels in Unit 1 yielded five leg bone fragments, including one fragment from a flotation sample taken in the first level $(0-10 \mathrm{~cm} \mathrm{bs})$. One metapodial fragment was found in Shovel Test 2 (depth unknown). Five pieces are burned. These are most likely the remains of deer rather than pronghorn (Antilocapra americana). Both are similar in size, but pronghorn antelope are found in open prairies and sagebrush plains well outside of the project area (Burt and Grossenheider 1980). The two are osteologically similar, but a specific identification was not made because of its fragmentation. Pronghorn currently reside in the western half of Texas from the Panhandle to the lower Rio Grande Valley (Davis 1978). However, one pronghorn element was recovered from the Hurricane Hill Site (41HP106), a Caddoan habitation

Table 6. Summary of Taphonomic Patterns on 41TT769 Faunal Assemblage.

\begin{tabular}{|c|c|c|c|c|c|}
\hline \multirow[t]{2}{*}{ Scientific Name } & \multirow{2}{*}{ Common Name } & \multicolumn{3}{|c|}{ Type of Taphonomy } & \multirow[b]{2}{*}{ abrade \& exfol } \\
\hline & & absent & abraded & exfoliated & \\
\hline Vertebrata (indeterminate) & unidentifiable & 26 & & & \\
\hline Osteichthyes (small) & sm. bony fish & 2 & & & \\
\hline Testudinata & turtle & 25 & & & \\
\hline Terrapene sp. & box turtle & 8 & & & \\
\hline Mammalia (indeterminate) & unid. mammal & 29 & & & \\
\hline Mammalia (large) & Ig. mammal & 53 & 19 & 5 & 1 \\
\hline Artiodactyla (medium) & deer-size artiodactyl & 3 & & 3 & \\
\hline \multirow[t]{2}{*}{ Odocoileus sp. } & deer & 1 & & & \\
\hline & TOTAL & 147 & 19 & 8 & 1 \\
\hline
\end{tabular}


site at Cooper Lake on the south Sulphur River in nearby Hopkins County (Yates 1999). Yates also states that Henderson (1978) reported pronghorn remains at the Arnold and Luna sites at Cooper Lake. Elk remains have also been found at another Cooper Lake site (Shaffer et al. 1995).

In addition to this quantity, artiodactyl is probably represented in the unidentifiable large mammal category $(\mathrm{n}=78)$. The large mammal and medium artiodactyl samples consist entirely of unidentifiable fragments and lower limb bones ("non-meat items"). Sixty-seven large mammal bones are burned, $38 \%$ of the site sample.

Table 7. Summary of Burning Patterns on 41 TT769 Faunal Specimens.

\begin{tabular}{|c|c|c|c|c|c|}
\hline & & & & & \\
\hline & & & & & \\
\hline Scientific Name & Common Name & Degree of & Burning & & \\
\hline & & not & charred & black & white \\
\hline Vertebrata (indeterminate) & unidentifiable & 10 & & & 16 \\
\hline Osteichthyes (small) & sm. bony fish & & & & 2 \\
\hline Testudinata & turtle & 6 & 5 & 1 & 13 \\
\hline Terrapene sp. & box turtle & 2 & 5 & & 1 \\
\hline Mammalia (indeterminate) & unid. mammal & 3 & 1 & 11 & 14 \\
\hline Mammalia (large) & Ig. mammal & 11 & 14 & 6 & 47 \\
\hline Artiodactyla (medium) & deer-size artiodactyl & 1 & 2 & 1 & 2 \\
\hline Odocoileus sp. & deer & & 1 & & \\
\hline & TOTAL & 33 & 28 & 19 & 95 \\
\hline
\end{tabular}

Table 8. Distribution of 41TT769 Burned Faunal Specimens by Unit and Level.

\begin{tabular}{|c|c|c|c|c|c|}
\hline \multirow{3}{*}{$\begin{array}{l}\text { Provenience } \\
\text { Shovel Test } 1 \\
(\mathrm{~B}=9)\end{array}$} & \multirow{2}{*}{ Scientific Name } & \multirow[t]{2}{*}{ Common Name } & \multicolumn{2}{|c|}{ Depth (cmbs) } & \\
\hline & & & 0to20 & 20to40 & \\
\hline & Mammalia (large) & Ig. mammal & 6 & 3 & \\
\hline \multirow{2}{*}{$\begin{array}{l}\text { Shovel Test } 2 \\
(B=1)\end{array}$} & & & \multicolumn{2}{|c|}{ unknown cmbs } & \\
\hline & Artiodactyla (medium) & deer-size artiodactyl & 1 & & \\
\hline \multicolumn{2}{|l|}{ Shovel Test 10} & & Oto10 & 20 to50 & \\
\hline$(B=5)$ & Mammalia (large) & Ig. mammal & 3 & 2 & \\
\hline Unit 1 & & & Oto10 & 10 to20 & 20 to30 \\
\hline \multirow[t]{9}{*}{$(B=127)$} & Vertebrata (indeterminate) & unidentifiable & & 9 & \\
\hline & Osteichthyes (small) & sm. bony fish & & 2 & \\
\hline & Testudinata & turtle & 5 & 12 & \\
\hline & Terrapene sp. & box turtle & & 6 & \\
\hline & Mammalia (indeterminate) & unid. mammal & 15 & 10 & 1 \\
\hline & Mammalia (large) & Ig. mammal & 19 & 28 & 6 \\
\hline & Artiodactyla (medium) & deer-size artiodactyl & 1 & 2 & 1 \\
\hline & Odocoileus sp. & deer & 1 & & \\
\hline & & TOTAL & 41 & 69 & 17 \\
\hline
\end{tabular}




\section{Assemblage Condition}

The James Owens site faunal collection is highly fragmented, explaining the low rate of identification. Taphonomic patterns are absent on 147 specimens (Table 6), 84\% of the entire site sample. Abrasion and exfoliation are visible on 28 fragments. A total of 142 specimens are burned, probably a result of trash disposal. Summary of burned specimens can be found in Table 7, and the distribution of these burned remains can be found in Table 8. A majority of faunal remains were recovered from flotation samples taken in three levels in Unit 1 (Table 9). Flotation samples yielded 78 very small fragments, $45 \%$ of the site collection (Table 10).

Table 9. Distribution of 41TT769 Faunal Flotation Recovery.

\begin{tabular}{|l|l|l|l|r|r|}
\hline & & & & \\
\hline & & & & \\
\hline Provenience & Scientific Name & Common Name & \multicolumn{2}{|l|}{ Depth (cmbs) } & \\
\hline Unit 1 & & & Oto10 & 10 to20 & 20 to30 \\
\hline$(\mathrm{N}=78)$ & Vertebrata (indeterminate) & unidentifiable & & 18 & 5 \\
\hline & Osteichthyes (small) & sm. bony fish & & 2 & \\
\hline & Testudinata & turtle & 5 & 2 & \\
\hline & Mammalia (indeterminate) & unid. mammal & 15 & 10 & \\
\hline & Mammalia (large) & Ig. mammal & 7 & 10 & \\
\hline & Artiodactyla (medium) & deer-size artiodactyl & 1 & & \\
\hline & Odocoileus sp. & deer & 1 & & \\
\hline & & TOTAL & 29 & 42 & \\
\hline
\end{tabular}

Table 10. Summary of 41TT769 Faunal Flotation Recovery.

\begin{tabular}{|l|l|r|}
\hline \multicolumn{2}{|c|}{} & \\
\hline Scientific Name & Common Name & NISP \\
\hline Vertebrata (indeterminate) & unidentifiable & 23 \\
\hline Osteichthyes (small) & sm. bony fish & 2 \\
\hline Testudinata & turtle & 7 \\
\hline Terrapene sp. & box turtle & 0 \\
\hline Mammalia (indeterminate) & unid. mammal & 25 \\
\hline Mammalia (large) & Ig. mammal & 19 \\
\hline Artiodactyla (medium) & deer-size artiodactyl & 1 \\
\hline Odocoileus sp. & deer & 1 \\
\hline & TOTAL & 78 \\
\hline
\end{tabular}

The condition of the bone suggests that at least some of the bone was boiled, possibly for bone grease processing. The degree of fragmentation also supports this conclusion. The bones are broken into small pieces and boiled in water. The floating fat is then skimmed from the top of the pot. The substance is used for frying and other culinary purposes. This practice has been well documented over time, and is a method used by many different cultures (Leechman 1951). 


\section{Distribution}

The following section is organized by analytical unit. Distribution of faunal remains by area is summarized in Table 11. Specific recovery by unit and level can be found in Table 12 .

Table 11. Summary of 41TT769 Faunal Distribution by Area

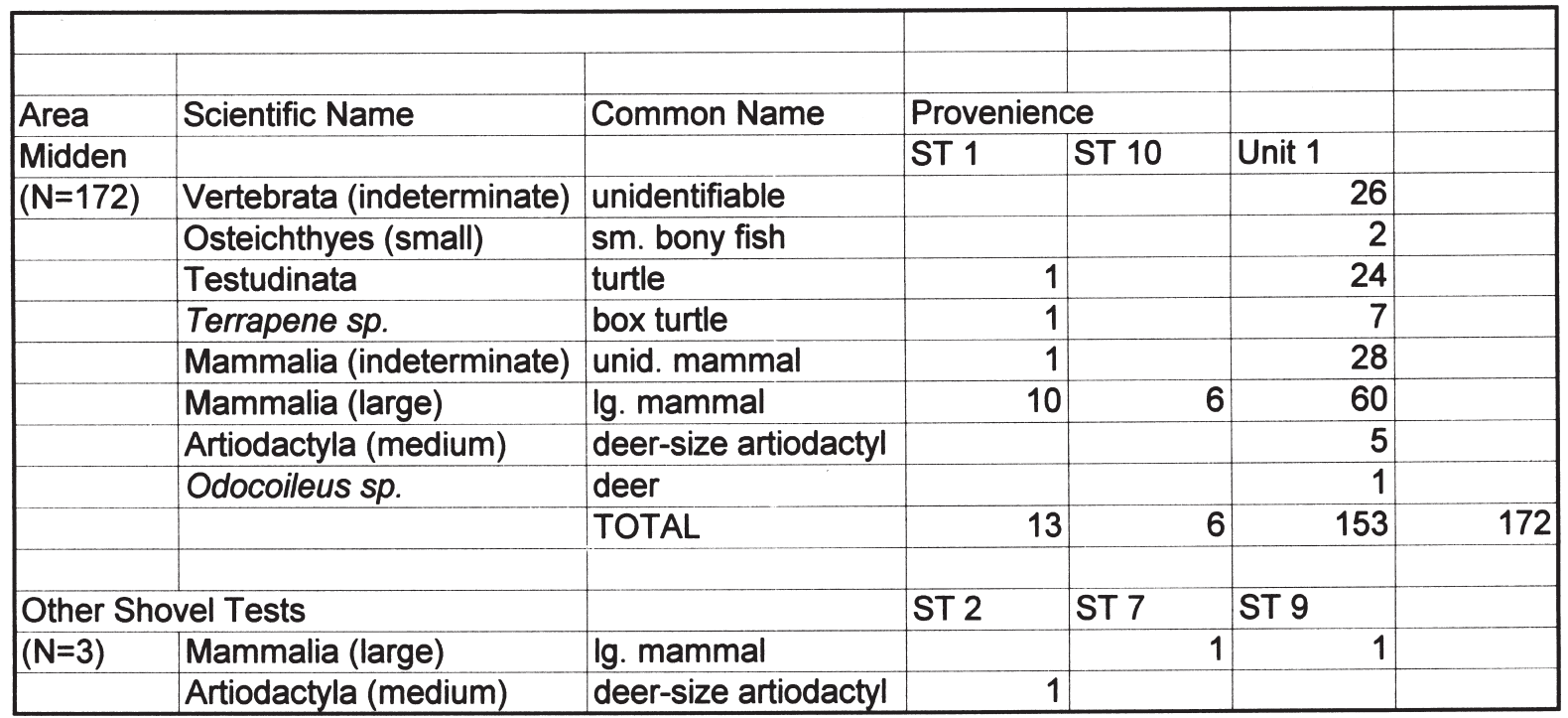

\section{Shovel Test 1 (Midden Area)}

Three levels in Shovel Test 1 yielded a total of 13 faunal specimens. The sample is dominated by large mammal remains, recovered from $0-20 \mathrm{~cm}$ bs $(\mathrm{n}=7)$. Three large mammal bone fragments, one indeterminate mammal bone fragment, and one piece of unidentifiable turtle shell were found in the second level $(20-40 \mathrm{~cm}$ bs). One box turtle shell fragment came from the third level $(40-50 \mathrm{~cm}$ bs). Nine specimens are burned.

\section{Shovel Test 2}

Only one faunal specimen was recovered from Shovel Test 2. This medium artiodactyl bone fragment is burned.

\section{Shovel Test 7}

One faunal specimen was recovered from Shovel Test 7, between 0-20 $\mathrm{cm}$ bs. This unidentifiable fragment from a large mammal is not burned, but it is abraded.

\section{Shovel Test 9}

One long bone fragment from an unidentifiable large mammal came from Shovel Test $9(0-20 \mathrm{~cm} \mathrm{bs})$. Abrasion and exfoliation are noted. The specimen is not burned.

\section{Shovel Test 10 (Midden Area)}

Shovel Test 10 yielded six large mammal bone fragments. Four pieces came from $0-10 \mathrm{~cm}$ bs, and two pieces came from $20-50 \mathrm{~cm}$ bs. Five specimens are burned. 
Table 12. Distribution of 41TT769 Faunal Specimens by Unit and Level.

\begin{tabular}{|c|c|c|c|c|c|}
\hline Provenience & Scientific Name & Common Name & \multicolumn{2}{|c|}{ Depth (cmbs) } & \\
\hline Shovel Test 1 & & & Oto20 & 20 to 40 & 40to50 \\
\hline \multirow{4}{*}{$(\mathrm{N}=13)$} & Testudinata & turtle & & 1 & \\
\hline & Terrapene sp. & box turtle & & & 1 \\
\hline & Mammalia (indeterminate) & unid. mammal & & 1 & \\
\hline & Mammalia (large) & Ig. mammal & 7 & 3 & \\
\hline \multirow{2}{*}{$\begin{array}{l}\text { Shovel Test } 2 \\
(\mathrm{~N}=1)\end{array}$} & & & \multicolumn{2}{|c|}{ unknown cmbs } & \\
\hline & Artiodactyla (medium) & deer-size artiodactyl & 1 & & \\
\hline \multirow{2}{*}{\begin{tabular}{|l|} 
Shovel Test 7 \\
$(\mathrm{~N}=1)$
\end{tabular}} & & & Oto20 & & \\
\hline & Mammalia (large) & Ig. mammal & 1 & & \\
\hline \multirow{2}{*}{$\begin{array}{l}\text { Shovel Test } 9 \\
(\mathrm{~N}=1)\end{array}$} & & & Oto20 & & \\
\hline & Mammalia (large) & Ig. mammal & 1 & & \\
\hline \multicolumn{2}{|l|}{ Shovel Test 10} & & Oto10 & 20 to50 & \\
\hline$(\mathrm{N}=6)$ & Mammalia (large) & Ig. mammal & 4 & 2 & \\
\hline Unit 1 & & & Oto10 & 10 to20 & 20to30 \\
\hline \multirow[t]{9}{*}{$(\mathrm{N}=153)$} & Vertebrata (indeterminate) & unidentifiable & & 18 & 8 \\
\hline & Osteichthyes (small) & sm. bony fish & & 2 & \\
\hline & Testudinata & turtle & 5 & 13 & 6 \\
\hline & Terrapene sp. & box turtle & 1 & 6 & \\
\hline & Mammalia (indeterminate) & unid. mammal & 15 & 10 & 3 \\
\hline & Mammalia (large) & Ig. mammal & 19 & 35 & 6 \\
\hline & Artiodactyla (medium) & deer-size artiodactyl & 2 & 2 & 1 \\
\hline & Odocoileus sp. & deer & 1 & & \\
\hline & & TOTAL & 43 & 86 & 24 \\
\hline
\end{tabular}

\section{Unit 1 (Midden Area)}

A total of 153 faunal specimens were recovered from three levels in Unit 1, and just over half came from the flotation sample in the midden deposits $(\mathrm{n}=78,51 \%)$. Depths range from $0-30 \mathrm{~cm}$ bs. The unit sample is dominated by large mammal bone fragments $(n=60)$, but also includes indeterminate vertebrate, unidentifiable fish, turtles, unidentifiable mammal, medium artiodactyl, and deer remains. One hundred twenty seven fragments are burned.

\section{Summary of the Faunal Remains}

The small faunal collection from the James Owens site gives further evidence to the fact that the prehistoric Caddo peoples supplemented their diet with large game, turtle, and fish, utilizing the rich resources of the Northeast Texas Post Oak Savannah. The sample reveals the potential for further investigations to yield additional information on prehistoric subsistence practices. 


\section{CONCLUSIONS}

The James Owens site (41TT769) is a multi-component prehistoric archeological site in the White Oak Creek basin of Northeast Texas. Thanks to the permission of the landowner, Mr. James Owens, we have been able to conduct archeological investigations at the site, and in the process we have gathered archeological information on the past settlement of this part of the Post Oak Savannah.

The first use of the site was during the Late Archaic to Woodland period (ca. 2800-1200 years ago). This component on the natural rise is marked primarily by discarded Gary and Yarbrough dart points, some fire-cracked rock from hot rock cooking of plant and animal remains, and a relatively dense deposit of locally-collected lithic debris from the manufacture and maintenance of stone tools.

The principal occupation of the James Owens site apparently took place between the $13^{\text {th }}$ to $15^{\text {th }}$ centuries A.D. by prehistoric Caddo peoples, and the occupation is marked by a midden deposit, high densities of ceramic sherds and daub/burned clay, as well as preserved animal bones of deer, turtle, and other species, mussel shells, and plant remains (primarily charred hickory nutshells). The midden may represent a trash deposit that accumulated in, or in the immediate vicinity of, a burned Caddo structure. The density of cooking jar sherds (the utility ware sherds decorated with brushing, punctation, applique, and incised lines), in combination with the estimated size of the midden, indicate that the midden may have accumulated (cf. Varien and Mills 1997) over ca. 20-30 years by at least one or two households.

The dominance of grog-bone tempered pottery at James Owens, in combination with a dominance of punctated and incised decorative elements, but with some brushed and brushed-incised jars-and a relatively abundant amount of red-slipped pottery in the assemblage-suggest social affiliations to other Caddo groups living in the White Oak Creek basin as well as living north and east (downstream) on the Sulphur River. Sites like the Cheatwood Place (41RR181, see Gaither et al. 1991) on Little Mustang Creek in the Sulphur River basin, Cheatwood Lake (41RR39), 41RR65 on Shawnee Creek (Heartfield, Price, and Greene, Inc. 1982), 41TT670, and 41BW553 (Largent et al. 1997) all have dense midden deposits from sedentary Caddo occupations. They represent what must have been a substantial population of Caddo peoples living in this part of the Post Oak Savannah in the one or two centuries immediately preceding initial European contacts in the mid- $16^{\text {th }}$ Century. The occasional shell-tempered sherd, from both Nash Neck Banded, Avery Engraved, and red-slipped vessels, in these Sulphur River basin sites point to some contacts with Caddo groups living to the north in the Red River valley. These same groups may have provided the non-local lithic raw materials that are also present on these sites.

Further work is planned at the James Owens site before Mr. Owens constructs a house there. This work will be to explore the midden deposits in more detail, so as to better estimate its size, contents, and rate of accumulation; locate other cultural features (particularly post holes and hearths from structures); collect more flotation samples to determine if maize or other cultigens were an important part of the Caddo diet at this locale; and obtain more radiocarbon samples from the midden and other cultural features. These will be crucial, along with the existing radiocarbon and OCR dates, in refining the estimated occupation span of the James Owens site. 


\section{ACKNOWLEDGMENTS}

We thank James and Sandra Owens for their permission to conduct archeological investigations on this important prehistoric Caddo Indian site on their property. Mark Parsons prepared the contour map of the site, and Sandra Hannum then prepared the figure used in this article. The costs of completing the radiocarbon, OCR, and faunal analyses were donated by Archeological \& Environmental Consultants, LLC.

\section{REFERENCES CITED}

Bankoff, H. A. and F. A. Winter

1979 A House-Burning in Serbia. Archaeology 32(5):8-14.

Burt, W. H. and R. P. Grossenheider

1980 A Field Guide to the Mammals. Peterson Field Guide Series, edited by R. T. Peterson. 3rd edition, Houghton Mifflin Co., Boston.

Conant, R.

1975 A Field Guide to Reptiles and Amphibians of Eastern and Central North America. Peterson Field Guide Series, 2nd edition. Houghton Mifflin Co., Boston.

Davis, W. B.

1978 The Mammals of Texas. Bulletin No. 41, revised. Texas Parks and Wildlife Department, Austin.

Fields, R. C., M. E. Blake, and K. W. Kibler

1997 Synthesis of the Prehistoric and Historic Archeology of Cooper Lake, Delta and Hopkins Counties, Texas. Reports of Investigations No. 104. Prewitt and Associates, Inc., Austin.

Gaither, S., T. K. Perttula, and G. Cheatwood

1991 The Cheatwood Place (41RR181), a Midden Mound along Little Mustang Creek, Red River County, Texas. Caddoan Archeology II, No. 1:21-28.

Gardner, P. S.

1997 The Ecological Structure and Behavioral Implications of Mast Exploitation Strategies. In People, Plants, and Landscapes: Studies in Paleoethnobotany, edited by K. J. Gremillion, pp. 161-178. University of Alabama Press, Tuscaloosa.

Gilbert, B. M.

1980 Mammalian Osteology. B. M. Gilbert, Publisher, Laramie, Wyoming.

Heartfield, Price, and Greene, Inc.

1982 A Cultural Resources Survey of High Probability Locations which will be affected by proposed Levee Construction within Angelina Farms, Red River County, Texas. Heartfield, Price, and Greene, Inc., Monroe.

Henderson, J.

1978 Faunal Analyses. In Evaluation of the Archaeology at the Proposed Cooper Lake, by K. Doehner, D. Peter, and S. A. Skinner. Research Report No. 114. Archaeology Research Program, Southern Methodist University, Dallas.

Largent, F. B., D. L. Beene, M. B. Cliff, and S. M. Hunt

1997 Cultural Resources Testing of Two Sites within the White Oak Creek Wildlife Management Area, Bowie and Titus Counties, Texas. Report of Investigations No. 6, White Oak Creek Mitigation Area Archeological Technical Series. Geo-Marine, Inc., Plano. 
Leechman, D.

1951 Bone Grease. American Antiquity 16(4):355.

Munzel, S.

1986 Quantitative Analysis and the Reconstruction of Site Patterning. Paper presented at the Vth International Conference of the International Council for ArchaeoZoology, Aug. 25-30, Bordeaux.

Newcomb, W.W., Jr.

1993 The Indians of Texas from Prehistoric to Modern Times. University of Texas Press, Austin.

Olsen, S. J.

1964 Mammal Remains from Archaeological Sites, Part I: Southeastern and Southwestern United States. Papers 56(1) of the Peabody Museum of Archaeology and Ethnology, Harvard University, Cambridge.

Roberts, K.

1990 Soil Survey of Camp, Franklin, Morris, and Titus Counties, Texas. United States Department of Agriculture, Soil Conservation Service, in cooperation with Texas Agricultural Experiment Station and Texas State Soil and Water Conservation Board.

Schambach, F. F.

1998 Pre-Caddoan Cultures in the Trans-Mississippi South. Research Series 53. Arkansas Archeological Survey, Fayetteville.

Schmid, E.

1972 Atlas of Animal Bones. Elsevier Publishing, Amsterdam.

Shaffer, B. S., B. C. Yates, and B. W. Baker

1995 An Additional Record of the Native American Elk (Cervus Elaphus) from North Texas. Texas Journal of Science 47(2):159-160.

Sherman, D. L, J. Hales, M. Nash, T. K. Perttula, and M. Tate Iruegas

2002 Data Recovery Investigations at the Ear Spool Site (41TT653), Titus County, Texas. Document No. 010350. Review draft. PBS\&J, Austin.

Stuiver, M. et al.

1998 INTCAL98 Radiocarbon Age Calibration. Radiocarbon 40(3):1041-1083.

Talma, A. S. and J. C. Vogel

1993 A Simplified Approach to Calibrating C14 Dates. Radiocarbon 35(2):317-322.

Teltser, P. A.

1993 An Analytic Strategy for Studying Assemblage-Scale Ceramic Variation: A Case Study from Southeast Missouri. American Antiquity 58(3):530-543.

Varien, M. D. and B. J. Mills

1997 Accumulations Research: Problems and Prospects for Estimating Site Occupation Span. Journal of Archaeological Method and Theory 4(2):141-191.

Yates, B. C.

1999 Vertebrate Fauna from Hurricane Hill. In The Hurricane Hill Site (41HP106): The Archaeology of a Late Archaicl Early Ceramic and Early-Middle Caddoan Settlement in Northeast Texas, Vol. I, edited by T. K. Perttula, pp. 345353. Special Publication No. 4, Friends of Northeast Texas Archaeology, Pittsburg and Austin. 